\title{
Pengaruh Budaya Organisasi, Pelatihan Dan Motivasi Terhadap Kinerja Karyawan Pada Universitas Tjut Nyak Dhien Medan
}

\author{
Hendra \\ Program Studi Magister Manajemen, Universitas Muhammadiyah Sumatera Utara Medan, Indonesia \\ Jl. Denai No. 217, Tegal Sari Mandala II, Medan Denai, Kota Medan, Sumatera Utara 20371 \\ Email: hendra@gmail.com
}

\begin{abstract}
Abstrak. Pentingnya peran sumber daya manusia dalam mencapai kinerja organisasi dengan kemampuan yang di miliki sumber daya manusianya. Artinya kemampuan sumber daya manusia harus benar-benar teruji sehingga mampu mengerjakan semua pekerjaan yang di bebankan kepadanya secara benar dan menghasilkan kinerja yang sempurna, baik kuantitas maupun kualitasnya. Di samping itu, pekerjaan haruslah dimotivasi secara terus-menerus agar tetap semangat untuk melakukan pekerjaannya. Banyak faktor yang mempengaruhi kinerja antara lain faktor budaya, pelatihan dan motivasi kerja. Tujuan dari penelitian ini adalah untuk mengetahui pengaruh budaya organisasi, pelatihan dan motivasi terhadap kinerja karyawan pada Universitas Tjut Nyak Dhien. Penelitian ini menggunakan pendekatan asosiatif, yaitu penelitian yang dilakukan untuk mengetahui pengaruh atau hubungan antara variabel bebas dengan variabel terikat. Hasil penelitian menunjukkan bahwa secara parsial budaya organisasi, pelatihan, dan motivasi memiliki pengaruh terhadap kinerja. Secara simultan budaya organisasi, pelatihan dan motivasi memiliki pengaruh yang signifikan terhadap kinerja.
\end{abstract}

Kata kunci: Budaya Organisasi, Pelatihan, Motivasi dan Kinerja

\begin{abstract}
The importance of the role of human resources in achieving organizational performance with the capabilities of its human resources. This means that the ability of human resources must be thoroughly tested so as to be able to do all the work that is assigned to him correctly and produce perfect performance, both in quantity and quality. In addition, work must be continuously motivated to stay motivated to do the work. Many factors affect performance including cultural factors, training and work motivation. The purpose of this study was to determine the effect of organizational culture, training and motivation on employee performance at Tjut Nyak Dhien University. This study uses an associative approach, namely research conducted to determine the effect or relationship between the independent variables with the dependent variable. The results showed that partially organizational culture, training dan motivation has a significant effect on performance. Simultaneously organizational culture, training and motivation have a significant influence on performance.
\end{abstract}

Keywords: Organizational Culture, Training, Motivation and Performance

\section{PENDAHULUAN}

Manajemen sumber daya manusia sangat penting bagi organisasi dalam mengelolah, mengatur, dan memanfaatkan karyawan secara produktif untuk tercapainya tujuan organisasi. Sumber daya manusia di dalam organisasi perlu di kelolah secara profesional agar terwujud keseimbangan antara kebutuhan karyawan dengan tuntutan dan kemampuan organisasi untuk menghasilkan kinerja (Daulay, Pasaribu, Putri, \& Astuti, 2017). Kinerja adalah hasil kerja secara kualitas yang dicapai oleh seorang pegawai dalam melaksanakan tugasnya sesuai dengan tanggung jawab yang diberikan kepadanya (Mangkunegara, 2016). 
Pentingnya peran sumber daya manusia dalam mencapai kinerja organisasi dengan kemampuan yang di miliki sumber daya manusianya. Artinya kemampuan sumber daya manusia harus benar-benar teruji sehingga mampu mengerjakan semua pekerjaan yang di bebankan kepadanya secara benar dan menghasilkan kinerja yang sempurna, baik kuantitas maupun kualitasnya. Di samping itu, pekerjaan haruslah dimotivasi secara terus-menerus agar tetap semangat untuk melakukan pekerjaannya. Banyak faktor yang mempengaruhi kinerja antara lain faktor budaya, pelatihan dan motivasi kerja (Kasmir, 2016).

Budaya organisasi yang baik dapat menjadi instrumen keunggulan kompetitif yang utama jika budaya organisasi mampu mendukung strategi organisasi dan mampu menjawab atau mengatasi tantangan lingkungan dengan cepat dan tepat. Budaya organisasi dapat berfungsi sebagai sistem perekat dan acuan prilaku untuk mencapai tujuan organisasi. Sebaliknya budaya organisasi yang buruk akan menghambat jalannya organisasi.

Pelatihan sering dianggap sebagai aktifitas yang paling dapat dilihat dan paling umum dari semua aktifitas kekaryawanan. Pelatihan yang baik dapat juga menunjang keberhasilan suatu perusahaan dalam mencapai tujuannya. Adanya pelatihan tersebut akan menciptakan kinerja karyawan yang tinggi sehingga dapat menunjang keberhasilan perusahaan. Kinerja karyawan merupakan suatu hal yang sangat penting dalam upaya perusahaan untuk mencapai tujuan. Dengan adanya kinerja yang tinggi yang dimiliki karyawan, diharapkan tujuan perusahaan yang diinginkan dapat tercapai.

Untuk meningkatkan kinerja karyawan dalam suatu organisasi, diperlukan adanya suatu dorongan yang disebut motivasi. Motivasi sebagai proses yang menjelaskan intensitas, arah dan ketekunan seorang individu untuk mencapai tujuannya. Pemberian motivasi biasanya dilakukan dari masing-masing perusahaan yang mengiinginkan adanya suatu kinerja karyawan yang tinggi di dalam perusahaannya. Kemampuan untuk memotivasi, mempengaruhi, mengarahkan dan berkomunikasi dengan para bawahannya akan menentukan efektivitas. Penelitian yang dilakukan oleh (Brahmasari \& Suprayetno, 2008), yaitu motivasi mempunyai pengaruh terhadap kinerja karyawan. Dengan demikian dapat disimpulkan semakin tinggi motivasi kerja yang dimiliki oleh seorang karyawan maka akan semakin meningkatkan kinerja karyawan tersebut.

Berdasarkan hasil observasi awal yang di lakukan, sehubungan dengan pembahasan mengenai budaya organisasi, pelatihan dan motivasi terhadap kinerja karyawan pada Universitas Tjut Nyak Dhien Medan. Karyawan merupakan asset penting pada Universitas Tjut Nyak Dhien Medan dalam mencapai keberhasilan Untuk menghadapi persaingan dengan Universitas sejenis dan untuk tetap bertahan ditengah persaingan yang cukup ketat diharapkan Universitas terus bergerak dengan melakukan inovasi dalam segi produk atau output yang dihasilkan. Untuk melakukan inovasi tersebut dibutuhkan SDM yang berkualitas. Demi tercapainya harapan tersebut, maka Universitas melakukan program pelatihan kepada karyawannya, menciptakan budaya organsiasi yang baik agar terbentuk tim kerja yang baik serta menumbuhkan motivasi untuk karyawan. Dengan program pelatihan yang dilaksanakan. Budaya organisasi yang baik serta pelatihan untuk karyawan diharapkan dapat meningkatkan rasa percaya diri sekaligus dapat meningkatkan kedisiplinan dalam bekerja sehingga karyawan tersebut dapat bekerja dengan baik, optimal dan lebih produktif sehingga Universitas dapat mencapai tujuan yang telah ditetapkan, yaitu kinerja karyawan yang lebih baik.

\section{LANDASAN TEORI \\ Kinerja}

Istilah kinerja berasal dari kata Job Performance atau Actual Performance (prestasi kerja atau prestasi sesungguhnya yang di capai oleh seseorang). Menurut (Moeheriono, 2014) 
mengemukan bahwa, kinerja atau performance merupakan gambaran mengenai tingkat pencapaian pelaksanaan suatu program kegiatan atau kebijakan dalam mewujudkan sasaran, tujuan, visi organisasi yang dituangkan melalui perencanaan strategis suatu organisasi. Pengertian kinerja menurut (Mangkunegara, 2016) adalah hasil kerja secara kualitas dan kuantitas yang di capai oleh seorang pegawai dalam melaksanakan tugasnya sesuai dengan tanggung jawab yang di berikan kepadanya. Selanjutnya pengertian kinerja menurut (Kasmir, 2016) kinerja merupakan hasil kerja dan perilaku kerja seseorang dalam suatu periode, biasanya 1 tahun". Kemudian pengertian kinerja menurut Miner dalam Sutrisno (2011, hal. 170), "kinerja adalah bagaimana sesorang yang diharapkan dapat berfungsi dan berperilaku sesuai dengan tugas yang telah dibebankan kepadanya. Sedangkan pendapat lain menjelaskan menurut Atmoseoprapto dalam (Agustini, 2011) bahwa kinerja adalah perbandingan antara keluaran (output) yang di capai dengan masukan (input) yang diberikan. Selain itu, kinerja juga merupakan hasil dari efesiensi pengelolaan masukan dan efektivitas pencapaian sasaran".

Menurut (M. S. . Hasibuan, 2014) mengungkapkan bahwa "Kinerja merupakan gabungan tiga faktor penting, yaitu kemampuan dan minat seorang pekerja,kemampuan dan penerimaan atas penjelasan delegasi tugas dan peran serta tingkat motivasi pekerja. Sedangkan menurut (Mangkunegara, 2014), kinerja (performance) dipengaruhi oleh tiga faktor yaitu: faktor individu, faktor psikologi dan faktor organisasi. Menurut (Sutrisno, 2014) faktor-faktor yang mempengaruhi kinerja yaitu 1) efektifitas dan efisiensi, 2) otoritas dan tanggung jawab, 3) disiplin kerja, dan 4) inisiatif. Untuk mengukur kinerja dapat di gunakan beberapa indikator mengenai kriteria kinerja yakni : kualitas, kuantitas, ketepatan waktu, efektivitas biaya, kebutuhan akan pengawasan, dan hubungan antar perseorangan. Indikator inilah yang akan menjadi patokan dalam mengukur kinerja, (Sutrisno, 2014). (Mangkunegara, 2016) mengemukakan bahwa indikator kinerja, yaitu : kualitas, kuantitas, kehandalan dan sikap.

\section{Budaya Organisasi}

Pengertian budaya organisasi menurut (Robbins, 2013) budaya organisasi adalah suatu system bersama yang dimiliki oleh setiap anggota suatu organisasi, yang dapat membedakan organisasi tersebut dari organisasi lainnya”. Kemudian pengertian budaya organisasi menurut (Luthans, 2006), bahwa : Budaya organisasi adalah norma-norma dan nilai-nilai yang mengarahkan perilaku anggota organisasi. Karena tentunya setiap anggota organisasi mempunyai kepribadian sendiri yang membedakannya. Salah satu faktor yang membedakan suatu organisasi dari organisasi lainnya adalah budayanya. Hal-hal tersebut penting dan karena itu perlu dipahami serta dikenali. Akan tetapi hal-hal yang bersifat universal tersebut harus diterapkan oleh manajemen dengan pendekatan yang memperhitungkan secara matang faktor-faktor situasi, sesuai kondisi, waktu dan ruang.

Menurut Mas'ud, (2004), budaya organisasional adalah sistem makna, nilai-nilai dan kepercayaan yang dianut bersama dalam suatu organisasi yang menjadi dasar untuk bertindak dan membedakan organisasi yang satu dengan organisasi yang lain, budaya organisasi selanjutnya menjadi identitas atau karakter utama organisasi yang dipelihara dan dipertahankan. Karakteristik utama yang menjadi pembeda budaya organisasi menurut (Robbins \& Judge, 2011) adalah: Inisiatif individual, toleransi terhadap tindakan beresiko, arah, integrasi, dukungan dari manajemen, pengawasan, identitas, sistem penghargaan, toleransi terhadap konflik dan pola komunikasi. Lebih lanjut (Robbins \& Judge, 2011) menyebutkan ada 7 (tujuh) karakteristik budaya organisasi sebagai berikut: inovasi dan keberanian mengambil resiko (inovation and risk taking), perhatian terhadap detil (attention to detail), berorientasi kepada hasil (outcome orientation), berorientasi kepada manusia (people orientation), berorientasi tim (team orientation), agresifitas (aggressiveness), stabilitas 
(stability). Indikator yang dapat digunakan untuk mengukur budaya organisasi (Luthans, 2006) yaitu regularitas perilaku yang diamati, norma-norma, nilai-nilai dominan, filosofi, aturan-aturan dan iklim organisasi.

\section{Pelatihan}

Pelatihan bagi karyawan perlu dilakukan agar karyawan mampu dan siap ditempatkan diposisi tertentu dalam perusahaan yang artinya mampu untuk bekerja dan mau untuk mematuhi segala aturan yang telah ditetapkan perusahaan. Pengertian pelatihan menurut (Kasmir, 2016) yaitu "Pelatihan merupakan proses untuk membentuk dan membekali karyawan dengan menambah keahlian, kemampuan, pengetahuan dan perilakunya artinya pelatihan akan membentuk perilaku karyawan sesuai dengan yang diharapkan perusahaan. Menurut (Hamali \& Budihastuti, 2019) yaitu : Pelatihan merupakan serangkaian aktivitas individu dalam meningkatkan keahlian dan pengetahuan secara sistematis sehingga mampu memiliki kinerja yang professional di bidangnya. Pelatihan adalah proses pembelajaran yang memungkinkan pegawai melaksanakan pekerjaan yang sekarang sesuai dengan standar. Sedangkan pengertian lain dari pelatihan menurut (Mangkunegara, 2016) bahwa "pelatihan adalah sebagai usaha untuk meningkatkan kinerja karyawan dalam pekerjaannya sekarang atau dalam pekerjaan lain yang akan dijabatnya segera". Faktor-faktor lain yang mempengaruhi pelatihan menurut (Mangkunegara, 2016) adalah perbedaan individu pegawai, hubungan dengan jabatan analisis, motivasi, partisipasi aktif, seleksi peserta penataran, metode pelatihan dan pengembangan. Faktor-faktor mengenai pelatihan menurut (Kasmir, 2016) yaitu: 1) peserta pelatihan, 2) instruktur/ pelatih, 3) materi pelatihan, 4) lokasi pelatihan, 5) lingkungan pelatihan, 6) waktu pelatihan. Menurut (Mangkunegara, 2016) indikator pelatihan adalah 1) instruktur, 2) peserta, 3) materi, 4) tujuan, 5) metode, 6) sasaran. Menurut (Siagian, 2014) yaitu 1) partisipasi, 2) materi pelatihan, 3) tingkat kesulitan kerja,4) transfer pengalihan.

\section{Motivasi}

Motivasi berasal dari kata motove atau dengan bahasa latinnya yaitu movere, yang berarti "mengarahkan". Menurut Nawawi, (2011) kata motivasi (motivation) berasal dari kata dasar motive yang berarti dorongan sebab atau alasan seseorang melakukan sesuatu. Dengan demikian motivasi merupakan kondisi yang mendorong atau membuat seseorang melaksanakan kegiatan secara langsung dengan sadar. Menurut (Martoyo, 2000) bahwa manusia dalam aktivitas kebiasaannya melakukan sesuatu asalkan dapat menghasilkan sesuatu yang menganggap dirinya memiliki suatu nilai yang sangat berharga, yang tujuannya untuk melangsungkan kehidupannya, rasa tentram, rasa aman dan sebagainya. Menurut (Bangun, 2012) yaitu, "motivasi adalah suatu tindakan untuk mempengaruhi orang lain agar berperilaku (to behave) secara teratur". Kemudian pengertian lain dari motivasi menurut (Manullang, 2012) yaitu, "motivasi adalah suatu kekuatan dari dalam atau luar diri manusia untuk mendorong semangat untuk mengejar sesuatu keinginan dan tujuan tertentu". Sedangkan pengertian motivasi menurut (Sutrisno, 2014) yaitu suatu faktor yang mendorong seseorang untuk melakukan suatu aktivitas tertentu, oleh karena itu motivasi sering kali diartikan pula sebagai faktor pendorong perilaku seseorang. Menurut (Samsuddin, 2009) mengemukakan bahwa motivasi adalah proses mempengaruhi atau mendorong dari luar terhadap seseorang atau kelompok kerja agar mereka mau melaksanakan sesuatu yang telah ditetapkan. Setiap aktivitas yang dilakukan oleh seseorang pasti memiliki suatu faktor yang mendorong aktivitas tersebut. Faktor yang mempengaruhi motivasi menurut (Sutrisno, 2014) menyatakan bahwa "faktor-faktor motivasi dibedakan atas faktor intern dan faktor ekstern yang berasal dari karyawan". Sedangkan indikator lain mengenai motivasi menurut (Mangkunegara, 2016) 
adalah : "kerja keras, orientasi masa depan, tingkat cita-cita yang tinggi, orientasi tugas dan keseriusan tugas, usaha untuk maju, ketekunan bekerja, hubungan dengan rekan kerja dan pemanfaatan waktu".

\section{METODE PENELITIAN}

Penelitian ini menggunakan pendekatan penelitian eksplanatori, yang bertujuan untuk menjelaskan hubungan sebab akibat antara variabel penelitian dan pengujian hipotesis (Nasution, Fahmi, Jufrizen, Muslih, \& Prayogi, 2020). Metode penelitian yang digunakan pada penelitian ini adalah kuantitatif, dimana variabel diukur dengan skala likert. Populasi penelitian ini adalah seluruh karyawan Universitas Tjut Nyak Dhien yang berjumlah 57 orang karyawan. Teknik pengumpulan data yang digunakan adalah menggunakan daftar pernyataan (angket). Teknik analisis data menggunakan analisis regresi linier berganda dan dalam pengolahan data menggunakan perangkat lunak SPSS versi 21.

\section{HASIL DAN PEMBAHASAN PENELITIAN Uji Asumsi Klasik Uji Normalitas}

Uji normalitas bertujuan untuk menguji apakah apakah dalam metode regresi, variabel terikat dan variabel bebas keduanya mempunyai distribusi normal atau tidak. Model regresi yang baik adalah data yang berdistribusi normal atau mendekati normal.Berikut adalah hasil pengujian normalitasdapat dilihat dari grafik probability plot, hasil penelitian data yang telah diolah dengan pengujian SPSS versi 21.0 adalah sebagai berikut:

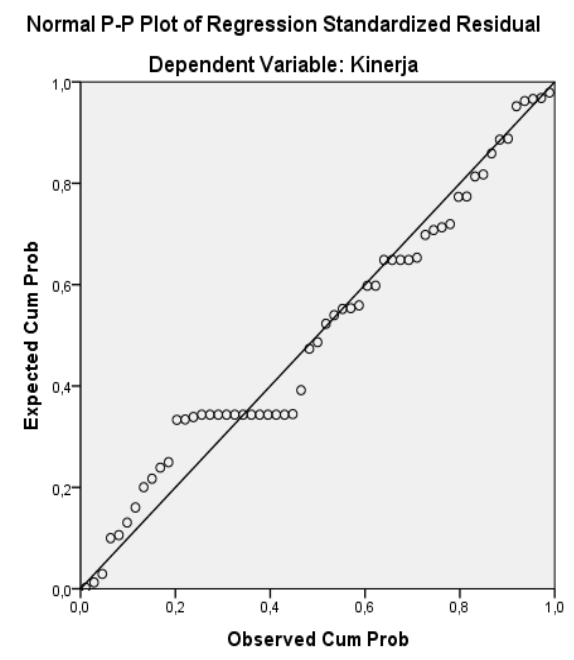

Sumber: Pengolahan data SPSS 2.1

\section{Gambar 1 Hasil Pengujian Normalitas}

Pada gambar diatas diketahui hasil dari pengujian normalitas bahwa data menunjukkan penyebaran titik-titik data cenderung mendekati garis diagonal. Sehingga dapat disimpulkan bahwa data yang diolah merupakan data yang berdistribusi normal dan uji normalitas terpenuhi.

\section{Uji Multikolinieritas}

Multikolinieritas digunakan untuk menguji apakah pada model regresi ditemukan adanya korelasi yang kuat antar variabel independen. Cara yang digunakan untuk menilainya adalah dengan melihat nilai faktor inflasi varians (Variance Inflasi Factor/VIF), yang tidak melebihi 10 . 
Tabel 1. Hasil Pengujian Multikolinearitas

\begin{tabular}{|c|c|c|c|c|c|c|}
\hline \multicolumn{7}{|c|}{ Coefficients $^{a}$} \\
\hline & & & prrelations & & Collinearit & tistics \\
\hline \multicolumn{2}{|c|}{ Model } & Zero-order & Partial & Part & Tolerance & VIF \\
\hline \multirow[t]{4}{*}{1} & (Constant) & & & & & \\
\hline & Budaya Organisasi & ,656 & ,021 & ,013 & 281 & 3,563 \\
\hline & Pelatihan & ,766 & ,533 & ,395 & 168 & 5,962 \\
\hline & Motivasi & ,572 & ,216 &,- 139 & 287 & 3,479 \\
\hline
\end{tabular}

a. Dependent Variable: Kinerja

Ketiga variabel independent yaitu $\mathrm{X}_{1}, \mathrm{X}_{2}$ dan $\mathrm{X}_{3}$ memiliki nilai VIF dalam batas toleransi yang telah ditentukan tidak melebihi 10 sehingga tidak terjadi multikolonieritas dalam variabel independen penelitian ini.

\section{Uji heteroskedastisitas}

Uji heteroskedastisitas bertujuan untuk menguji apakah dalam model regresi terjadi ketidaknyamanan vaiance dari residual pengamatan satu ke pengamatan yang lain. Jika varian dari residual satu pengamatan ke pengamatan lain tetap, maka disebut homokedassitas dapat diketahui dengan melalui grafik scatterplot antar nilai prediksi varabel independen dengan nilai residualnya

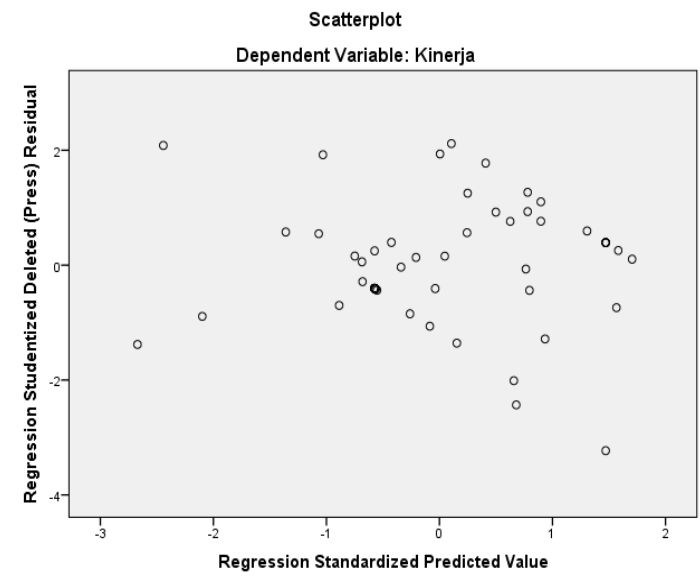

Sumber: Pengolahan data SPSS 2.1

\section{Gambar 2. Hasil Pengujian Heteroskedasitas}

Dari gambar grafik scatterplot diatas dapat diketahui bahwa tidak terjadi heteroskedastisitas pada model regresi ini. Sebab tidak ada pola yang jelas serta titik-titik menyebar diatas dan dibawah angka 0 pada sumbu Y, maka kesimpulannya tidak terjadi heteroskedasitas.

\section{Pengujian Hipotesis}

\section{Uji t (Secara Parsial)}

Tujuan dari Uji t adalah untuk melihat apakah ada hubungan yang signifikan atau tidak dalam hubungan antara variabel $\mathrm{X}_{1}, \mathrm{X}_{2}$ dan $\mathrm{X}_{3}$ terhadap $\mathrm{Y}$. data tersaji pada tabel di bawah ini, adapun $\mathrm{t}_{\text {tabel }}=1.674$ (lihat tabel $\mathrm{t}$ untuk $\mathrm{N}=33$ ). 
Tabel 2. Uji t

\begin{tabular}{|c|c|c|c|c|c|c|}
\hline \multicolumn{7}{|c|}{ Coefficients $^{a}$} \\
\hline \multirow[b]{2}{*}{ Mode } & & \multicolumn{2}{|c|}{$\begin{array}{c}\text { Unstandardized } \\
\text { Coefficients }\end{array}$} & \multirow{2}{*}{$\begin{array}{c}\begin{array}{c}\text { Standardized } \\
\text { Coefficients }\end{array} \\
\text { Beta }\end{array}$} & \multirow[b]{2}{*}{$\mathrm{T}$} & \multirow[b]{2}{*}{ Sig. } \\
\hline & & $\mathrm{B}$ & Std. Error & & & \\
\hline 1 & (Constant) & 20,474 & 3,588 & & 5,706 &, 000 \\
\hline & Budaya Organisasi & 1,064 & 165 & ,656 & 6,439 &, 000 \\
\hline
\end{tabular}

Sumber : Hasil Penelitian (2019)

\section{Pengaruh Budaya Organisasi Terhadap Kinerja}

Hasil pengujian diperoleh nilai t untuk variabel budaya organisasi menunjukkan nilai $\mathrm{t}_{\text {hitung }} 6.439 \geq \mathrm{t}_{\text {tabel }} 1.674$ dengan probabilitas Sig 0.000 lebih kecil dari $\alpha=0,05$ dengan demikian berarti budaya organisasi memiliki pengaruh yang signifikan terhadap kinerja yang berarti Hipotesis diterima.

\section{Pengaruh Pelatihan Terhadap Kinerja}

Hasil pengujian diperoleh nilai $t$ untuk variabel pelatihan menunjukkan nilai $t_{\text {hitung }} 8.847$ $\geq \mathrm{t}_{\text {tabel }} 1.674$ dengan probabilitas Sig 0.000 , lebih kecil dari $\alpha=0,05$ yang berarti menunujukkan bahwa pelatihan memiliki pengaruh yang signifikan terhadap kinerja hal ini berarti Hipotesis diterima.

\section{Pengaruh Motivasi terhadap Kinerja}

Hasil pengujian diperoleh nilai $t$ untuk variabel motivasi menunjukkan nilai $t_{\text {hitung }} 5.178$ $\geq t_{\text {tabel }} 1.674$ dengan probabilitas Sig 0.000 , lebih kecil dari $\alpha=0,05$ yang berarti menunujukkan bahwa motivasi memiliki pengaruh yang signifikan terhadap kinerja hal ini berarti Hipotesis diterima.

\section{Uji F (Secara Simultan)}

Hasil perhitungan Uji F disajikan pada tabel di bawah ini :

Tabel 3. Hasil Uji F

\begin{tabular}{|c|c|c|c|c|c|c|}
\hline \multicolumn{7}{|c|}{ ANOVA $^{a}$} \\
\hline Model & & Sum of Squares & $d f$ & Mean Square & $\mathrm{F}$ & Sig. \\
\hline \multirow[t]{3}{*}{1} & Regression & 771,284 & 3 & 257,095 & 27,253 &, $000^{\circ}$ \\
\hline & Residual & 499,979 & 53 & 9,434 & & \\
\hline & Total & 1271,263 & 56 & & & \\
\hline
\end{tabular}

b. Predictors: (Constant), Motivasi, Budaya Organisasi, Pelatihan

Sumber : Data diolah (2019)

Dari hasil pengolahan data di atas terlihat bahwa nilai $\mathrm{F}_{\text {hitung }}=27.253>$ dari $\mathrm{F}_{\text {tabel }}=2.55$ (lihat tabel $\mathrm{F}$ untuk $\mathrm{N}=33$ ) dengan nilai probabilitas yakni sig adalah sebesar $0,000<0,05$. Artinya budaya organisasi, pelatihan dan motivasi secara bersama-sama berpengaruh signifikan terhadap kinerja, maka keputusannya Hipotesis diterima.

\section{Koefisien Determinasi $\left(\mathbf{R}^{2}\right)$}

Koefisien determinasi ini digunakan untuk mengetahui seberapa besar pengaruh variabel-variabel bebas memiliki pengaruh terhadap variabel terikatnya. Nilai koefisien determinasi ditentukan dengan nilai $R$ square. 
Tabel 4. Koefisien Determinasi

\begin{tabular}{lccccc}
\hline Model & $\mathrm{R}$ & $\mathrm{R}$ Square & $\begin{array}{c}\text { Adjusted R } \\
\text { Square }\end{array}$ & $\begin{array}{c}\text { Std. Error of the } \\
\text { Estimate }\end{array}$ \\
\hline 1 &, $779^{\mathrm{a}}$ &, 607 &, 584 & 3,07141 \\
\hline a. Predictors: (Constant), Motivasi, Budaya Organisasi, Pelatihan & \\
\hline \multicolumn{4}{l}{ b. Dependent Variable: Kinerja } \\
\hline
\end{tabular}

Sumber : Hasil Penelitian (2019)

Dari hasil pengolahan data di atas terlihat bahwa nilai koefisien korelasi (R Square) sebesar 0,607, hal ini berarti budaya organisasi, pelatihan dan motivasi secara bersama-sama berpengaruh sebesar 60,7\% sedangkan sisanya 39,3\% kinerja dipengaruhi oleh variabel lain yang tidak ada dalam penelitian ini.

\section{PEMBAHASAN}

\section{Pengaruh Budaya Organisasi terhadap Kinerja}

Berdasarkan hasil penelitian mengenai pengaruh antara budaya organisasi terhadap kinerja karyawan pada Universitas Tjut Nyak Dhien yang menyatakan thitung $\geq$ ttabel yaitu $6.439 \geq 1.674$ berada di daerah penerimaan Ha sehingga H0 ditolak, hal ini dinyatakan bahwa budaya organisasi berpengaruh signifikan secara parsial terhadap kinerja karyawan di Universitas Tjut Nyak Dhien. Hal ini berarti bahwa semakin budaya organisasi makan akan berdampak kepada peningkatakan kinerja karyawan, sebaliknya semakin buruk budaya organisasi suatu perusahaan maka berdampak kepada penurunan kinerja karyawan. Hasil penelitian ini menyatakan bahwa ada pengaruh antara budaya organisasi terhadap kinerja. Hasil penelitian ini sejalan dengan hasil penelitian terdahulu (Jufrizen, 2017a); (Jufrizen, 2017c); (Muis, Jufrizen, \& Fahmi, 2018); (Jufrizen, Lumbanraja, Salim, \& Gultom, 2017); (Jufrizen, Gultom, Sitorus, Sari, \& Nasution, 2018); (Gultom, 2014); (Arif, 2018); (Ainanur \& Tirtayasa, 2018); (Andayani \& Tirtayasa, 2019); (Wahyudi \& Tupti, 2019); (Muhamamd Andi Prayogi \& Rialdy, 2018); (Arianty, 2014); dan (Yusnandar, Nefri, \& Siregar, 2020) yang menyimpulkan bahwa terdapat pengaruh antara budaya organisasi terhadap kinerja.

\section{Pengaruh Pelatihan terhadap Kinerja}

Berdasarkan hasil penelitian mengenai pengaruh antara pelatihan terhadap kinerja karyawan pada Universitas Tjut Nyak Dhien yang menyatakan thitung $\geq$ ttabel yaitu $8.847 \geq$ 1.674 berada di daerah penerimaan Ha sehingga $\mathrm{H} 0$ ditolak, hal ini di nyatakan bahwa pelatihan berpengaruh signifikan secara parsial terhadap kinerja karyawan di Universitas Tjut Nyak Dhien. Hal ini berarti bahwa semakin baik pelatihan yang diberikan akan berdampak kepada peningkatakan kinerja karyawan, sebaliknya semakin kurang baik pelatihan yang diberikan maka berdampak kepada penurunan kinerja karyawan. Hasil penelitian ini menyatakan bahwa ada pengaruh antara pelatihan terhadap kinerja. Hal ini sejalan dengan hasil penelitian terdahulu (Elizar \& Tanjung, 2018); (Prayogi \& Nursidin, 2018); (Astuti \& Sari, 2018); (Yusnandar et al., 2020); dan (Mutholib, 2019) yang menyimpulkan bahwa terdapat pengaruh antara pelatihan terhadap kinerja.

\section{Pengaruh Motivasi terhadap Kinerja}

Berdasarkan hasil penelitian mengenai pengaruh antara motivasi terhadap kinerja pada Universitas Tjut Nyak Dhien yang menyatakan thitung $\geq$ ttabel yaitu $5.178 \geq 1.674$ berada di daerah penerimaan Ha sehingga $\mathrm{H} 0$ ditolak, hal ini di nyatakan bahwa motivasi berpengaruh signifikan secara parsial terhadap kinerja karyawan di Universitas Tjut Nyak Dhien. Hal ini berarti bahwa semakin tinggi/baik motivasi kerja karyawam maka akan berpengaruh kepada peningkatan kinerja karyawan, sebaliknya semakin rendah motivasi kerja karyawan akan 
berpengaruh kepada penurunan kinerja karyawan. Hasil penelitian ini menyatakan bahwa ada pengaruh antara motivasi terhadap kinerja. Hal ini sejalan dengan hasil penelitian terdahulu yang dilakukan oleh (Jufrizen \& Pulungan, 2017); (Jufrizen, 2017); (Jufrizen, 2018); (Rosmaini \& Tanjung, 2019); (Gultom, 2014); (Ainanur \& Tirtayasa, 2018); (Astuti \& Lesmana, 2018); (Marjaya \& Pasaribu, 2019); (Siahaan \& Bahri, 2019); (Wahyudi \& Tupti, 2019); (Hasibuan \& Handayani, 2017); (Farisi, Irnawati, \& Fahmi, 2020); (Bukhari \& Pasaribu, 2019); (Mujiatun, 2015); (Astuti \& Suhendri, 2019); (Tanjung, 2015) dan (Hasibuan \& Bahri, 2018) yang menyimpulkan bahwa terdapat pengaruh antara motivasi terhadap kinerja.

\section{Pengaruh Budaya Organisasi, Pelatihan dan Motivasi terhadap Kinerja}

Berdasarkan hasil penelitian mengenai pengaruh antara budaya organisasi, pelatihan dan motivasi terhadap kinerja karyawan di Universitas Tjut Nyak Dhien pada penelitian ini sudah jelas terbukti ada pengaruh secara simultan, di mana hasil uji $\mathrm{F}$ di dapat nilai Fhitung $\geq$ Ftabel yaitu $27.253 \geq 2.55$ dengan signifikan $0,000<0,05$. Karena Fhitung lebih besar dari Ftabel maka H0 di tolak dan Ha di terima artinya ada pengaruh antara budaya organisasi, pelatihan dan motivasi terhadap kinerja karyawan di Universitas Tjut Nyak Dhien. Hasil penelitian ini menyatakan bahwa ada pengaruh antara budaya organisasi, pelatihan dan motivasi terhadap kinerja. Hal ini sejalan dengan hasil penelitian terdahulu (Herminingsih \& Kreestianawati, 2016) yang menunjukkan bahwa budaya organisasi, pelatihan dan motivasi berpengaruh terhadap kinerja.

\section{KESIMPULAN}

Berdasarkan hasil penelitian dan pembahasan yang di lakukan oleh peneliti mengenai pengaruh budaya organisasi, pelatihan dan motivasi terhadap kinerja karyawan di Universitas Tjut Nyak Dhien, maka dapat di tarik kesimpulan bahwa budaya organisasi secara parsial berpengaruh signifikan terhadap kinerja. Pelatihan secara parsial berpengaruh signifikan terhadap kinerja. Motivasi secara parsial berpengaruh signifikan terhadap kinerja. Budaya organisasi, pelatihan dan motivasi secara simultan berpengaruh signifikan terhadap kinerja.

Berdasarkan kesimpulan diatas, maka dalam hal ini penulis dapat menyarankan hal-hal yaitu : 1) Budaya organisasi yang baik dapat berfungsi sebagai sistem perekat dan acuan prilaku untuk mencapai tujuan organisasi. Sebaliknya budaya organisasi yang buruk akan menghambat jalannya organisasi. Untuk itu sebaiknya budaya organisasi karyawan terus diperhatikan dan diperbaiki seperti menerapkan disiplin yang baik sehingga kinerja karyawan dapat meningkat, 2) Pelatihan yang baik dapat juga menunjang keberhasilan universitas dalam mencapai tujuannya. Adanya pelatihan tersebut akan menciptakan kinerja karyawan yang tinggi sehingga dapat menunjang keberhasilan universitas. Untuk itu sebaiknya universitas memberikan fasilitas pelatihan kepada karyawan seperti Skill Training (Pelatihan Keahlian), Retraining (Pelatihan Ulang), Cross Functional Training, Team Training (Pelatihan Tim) dan Creativity Training. Namun kegiatan tersebut terus dipantau dalam pelaksanaannya sehingga meminimalisir karyawan yang tidak mengikuti pelatihan, 3) Untuk meningkatkan kinerja karyawan dalam suatu organisasi, diperlukan adanya suatu dorongan yang disebut motivasi. Maka dari itu sebaiknya karyawan terus diberikan motivasi agar mereka bersemangat dalam melaksanakan pekerjaan. 4) Sebuah universitas yang hebat tentu membutuhkan Sumber Daya Manusia (SDM) yang hebat pula. Pada masa sekarang ini, persaingan bisnis semakin ketat, maka produktivitas SDM harus ditingkatkan untuk menjaga keberlangsungan organisasi. Untuk itu, universitas diharapkan dapat membentuk budaya organisasi yang lebih baik, memberikan program pelatihan dan pengembangan SDM harus dilaksanakan agar dapat mengatasi permasalahan ini, serta terus memberikan motivasi kepada karyawan agar kinerja 
dapat terus meningkat. 5) Bagi para peneliti selanjutnya yang akan melakukan penelitian diharapkan agar dapat mencari referensi yang lain untuk lebih menambah variasi pada dimensi dan indikator-indikator variabel yang telah dilakukan pada penelitian sebelumnya.

\section{DAFTAR PUSTAKA}

Agustini, F. (2011). Manajemen Sumber Daya Manusia Lanjutan. Medan: Madenatera.

Ainanur, A., \& Tirtayasa, S. (2018). Pengaruh Budaya Organisasi, Kompetensi dan Motivasi Terhadap Kinerja Karyawan. Maneggio: Jurnal Ilmiah Magister Manajemen, 1(1), 1-14. https://doi.org/10.30596/maneggio.v1i1.2234

Andayani, I., \& Tirtayasa, S. (2019). Pengaruh Kepemimpinan, Budaya Organisasi, Dan Motivasi Terhadap Kinerja Pegawai. Maneggio: Jurnal Ilmiah Magister Manajemen, 2(1), 45-54. https://doi.org/10.30596/maneggio.v2i1.3367

Arianty, N. (2014). Pengaruh Budaya Organisasi Terhadap Kinerja Pegawai. Jurnal Ilmiah Manajemen Dan Bisnis, 14(2), 144-150.

Arif, M. (2018). Effect of Organization Commitments and Organization Culture on the Performance of Employees in Garuda Plaza Hotel. In Internasional Conference on Global Education VI (pp. 1247-1259).

Astuti, R., \& Lesmana, O. P. A. (2018). Pengaruh Motivasi dan Beban Kerja Terhadap Kinerja Perawat Pada Rumah Sakit Umum Mitra Medika Medan. Jurnal Ilmu Manajemen, 6(2), 42-50.

Astuti, R., \& Sari, I. (2018). Pengaruh Pelatihan dan Kompensasi Terhadap Kinerja Karyawan Pada PT. Kemasindo Cepat Nusantara Medan. In Prosiding Seminar Nasional Royal (SENAR) 2018 (pp. 461-464).

Astuti, R., \& Suhendri, S. (2019). Pengaruh Kompensasi Dan Motivasi Terhadap Kinerja Karyawan pada PT. Tunas Jaya Utama. Jurnal Manajemen Bisnis Eka Prasetya: Penelitian Ilmu Manajemen, 5(2), 1-10.

Bangun, W. (2012). Manajemen Sumber Daya Manusia. Jakarta: Erlangga.

Brahmasari, I. A., \& Suprayetno, A. (2008). Pengaruh Motivasi Kerja, Kepemimpinan dan Budaya Organisasi Terhadap Kepuasan Kerja Karyawan serta Dampaknya pada Kinerja Perusahaan (Studi kasus pada PT. Pei Hai International Wiratama Indonesia). Jurnal Manajemen Dan Kewirausahaan, 10(2), 124-135. https://doi.org/10.9744/jmk.10.2.pp.\%20124-135

Bukhari, B., \& Pasaribu, S. E. (2019). Pengaruh Motivasi, Kompetensi, Dan Lingkungan Kerja Terhadap Kinerja. Maneggio : Jurnal Ilmiah Magister Manajemen, 2(1), 89-103.

Daulay, R., Pasaribu, H. K., Putri, L. P., \& Astuti, R. (2017). Manajemen. Medan: Lembaga Penelitian dan Penulisan Ilmiah AQLI.

Elizar, E., \& Tanjung, H. (2018). Pengaruh Pelatihan, Kompetensi, Lingkungan Kerja terhadap Kinerja Pegawai. Maneggio: Jurnal Ilmiah Magister Manajemen, 1(1), 46-58. https://doi.org/10.30596/maneggio.v1i1.2239

Farisi, S., Irnawati, J., \& Fahmi, M. (2020). Pengaruh Motivasi dan Disiplin Kerja Terhadap Kinerja Karyawan. Jurnal Humaniora: Jurnal Ilmu Sosial, Ekonomi Dan Hukum, 4(1), 15-33. https://doi.org/10.30601/humaniora.v4i1.420

Gultom, D. K. (2014). Pengaruh Budaya Organisasi Perusahaan Dan Motivasi Terhadap Kinerja Karyawan pada PT. Perusahaan Gas Negara (Persero) Tbk Medan. Jurnal Ilmiah Manajemen Dan Bisnis, 14(2), 176-184. https://doi.org/10.30596/jimb.v14i2.194

Hamali, A. Y., \& Budihastuti, E. S. (2019). Pemahaman Praktis Administrasi, Organisasi, Dan Manajemen Strategi Mengelola Kelangsungan Hidup Organisasi (1st ed.). Jakarta: Prenadamedia Group. 
Hasibuan, J. S., \& Handayani, R. (2017). Pengaruh Disiplin dan Motivasi Terhadap Kinerja Karyawan Pada PT. Kemasindo Cepat Nusantara Medan. Kumpulan Jurnal Dosen Universitas Muhammadiyah Sumatera Utara, 418-428.

Hasibuan, M. S. . (2014). Manajemen Sumber Daya Manusia. Jakarta: Bumi Aksara.

Hasibuan, S. M., \& Bahri, S. (2018). Pengaruh Kepemimpinan, Lingkungan Kerja dan Motivasi Kerja terhadap Kinerja. Maneggio: Jurnal Ilmiah Magister Manajemen, 1(1), 71-80. https://doi.org/10.30596/maneggio.v1i1.2243

Herminingsih, A., \& Kreestianawati, K. (2016). Pengaruh Pelatihan, Motivasi Kerja Dan Budaya Organisasi Terhadap Kinerja Pegawai Negeri Sipil. Jurnal Ilmu Ekonomi Dan Sosial, 5(3), 241-257.

Jufrizen, J. (2017). Efek Moderasi Etika Kerja Pada Pengaruh Kepemimpinan Transformasional dan Budaya Organisasi Terhadap Kinerja Karyawan. E-Mabis : Jurnal Ekonomi Manajemen Dan Bisnis, 18(2), 145-158. https://doi.org/10.29103/e-mabis.v18i2.180

Jufrizen, J. (2017). Pengaruh kemampuan dan motivasi terhadap kinerja perawat Studi pada Rumah Sakit Umum Madani Medan. Jurnal Riset Sains Manajemen, 1(1), 27-34. https://doi.org/10.5281/zenodo.1036809

Jufrizen, J. (2017). Pengaruh Kepemimpinan dan Budaya Organisasi Terhadap Kinerja dengan Kepuasan Kerja sebagai Variabel Intervening. Jurnal Ilmiah Kohesi, 1(1), 166-177.

Jufrizen, J. (2018). Peran Motivasi Kerja dalam Memoderasi Pengaruh Kompensasi dan Disiplin Kerja terhadap Kinerja Karyawan. In Prosiding: The National Conferences Management and Business (NCMAB) 2018 (pp. 405-424).

Jufrizen, J., Gultom, D. K., Sitorus, S. A., Sari, M., \& Nasution, M. I. (2018). The Effect of Organizational Culture and Islamic Work Ethic on Permanent Lecturers' Job Satisfaction, Organizational Commitment And Work Performance at Private Islamic Universities in the City of Medan. In Proceeding 1st International Conference of Economic Studies (ICOES) 2018 (pp. 179-186).

Jufrizen, J., Lumbanraja, P., Salim, S. R. A., \& Gultom, P. (2017). The Effect of Compensation, Organizational Culture and Islamic Work Ethic Towards the Job Satisfaction and the Impact on the Permanent Lecturers. International Business Management, 11(1), 53-60.

Jufrizen, J., \& Pulungan, D. R. (2017). Implementation of Incentive and Career Development of Performance with Motivation as an Intervening Variable. In Proceedings of AICS-Social Sciences (pp. 441-446).

Kasmir. (2016). Manajemen Sumber Daya Manusia Teori dan Praktik. Depok: Rajawali Pers. Luthans, F. (2006). Perilaku Organisasi. Yogyakarta: Andi.

Mangkunegara, A. A. A. P. (2014). Evaluasi Kinerja Sumber Daya Manusia. Bandung: Refika Aditama.

Mangkunegara, A. A. A. P. (2016). Manajemen Sumber Daya Manusia Perusahaan. Bandung: PT. Remaja Rosdakarya.

Manullang, M. (2012). Dasar-Dasar Manajemen. Yogyakarta: Gadjah Mada University Press. Marjaya, I., \& Pasaribu, F. (2019). Pengaruh Kepemimpinan, Motivasi, Dan Pelatihan Terhadap Kinerja Pegawai. Maneggio: Jurnal Ilmiah Magister Manajemen, 2(1), 129147. https://doi.org/10.30596/maneggio.v2i1.3650

Martoyo, S. (2000). Manajemen Sumber Daya Manusia. Yogyakarta: BPFE.

Mas'ud, F. (2004). Survai Diagnosis Organisasional (Konsep dan Aplikasi). Semarang: BPUniversitas Diponegoro.

Moeheriono, M. (2014). Pengukuran Kinerja Berbasis Kompetensi (Revisi). Jakarta: PT Raja Grafindo Persada. 
Muis, M. R., Jufrizen, J., \& Fahmi, M. (2018). Pengaruh Budaya Organisasi Dan Komitmen Organisasi Terhadap Kinerja Karyawan. Jesya (Jurnal Ekonomi \& Ekonomi Syariah), $1(1), 9-25$.

Mujiatun, S. (2015). Pengaruh Kepuasan Kerja dan Motivasi Kerja Terhadap Kinerja Pada PT Rajawali Nusindo Medan. Jurnal Ilmiah Manajemen Dan Bisnis, 16(2).

Mutholib, M. (2019). Pengaruh Pelatihan Kerja dan Kompensasi Finansial Terhadap Kinerja. Liabilities Jurnal Pendidikan Akutansi, 2(3), 222-236.

Nasution, M. I., Fahmi, M., Jufrizen, J., Muslih, M., \& Prayogi, M. A. (2020). The Quality of Small and Medium Enterprises Performance Using the Structural Equation Model-Part Least Square (SEM-PLS). Journal of Physics: Conference Series, 1477(2020), 1-7. https://doi.org/10.1088/1742-6596/1477/5/052052

Nawawi, H. (2011). Manajemen Sumber Daya Manusia: Untuk Bisnis Yang Kompetitif. Yogyakarta: UGM Press.

Prayogi, M. A., \& Rialdy, N. (2018). Pengaruh Budaya Organisasi dan Kompetensi Terhadap Kinerja Karyawan Karayawan Pada PT. Boga Indo Sejahtera Abadi (Restaurant Paraside Dynansty). Prosiding Ekonomi, Manajemen Dan Akutansi, 19.

Prayogi, M.A., \& Nursidin, M. (2018). Pengaruh Pelatihan dan Motivasi Kerja Terhadap Kinerja Karyawan. In Prosiding Seminar Nasional Multidisiplin Ilmu Universitas Asahan 2018 (pp. 216-222).

Robbins, S. P. (2013). Perilaku Organisasi, Konsep, Kontroversi, Aplikasi. Jakarta: Prenhallindo.

Robbins, S. P., \& Judge, T. A. (2011). Organizational Behavior (14th ed.). New Jersey: Prentice Hall.

Rosmaini, R., \& Tanjung, H. (2019). Pengaruh Kompetensi, Motivasi Dan Kepuasan Kerja Terhadap Kinerja Pegawai. Maneggio: Jurnal Ilmiah Magister Manajemen, 2(1), 1-15. https://doi.org/10.30596/maneggio.v2i1.3366

Samsuddin, S. (2009). Manajemen Sumber Daya Manusia. Bandung: Pustaka Setia.

Siagian, S. P. (2014). Manajemen Sumber Daya Manusia. Jakarta: Bumi Aksara.

Siahaan, S., \& Bahri, S. (2019). Pengaruh Penempatan Pegawai, Motivasi, Dan Lingkungan Kerja Terhadap Kinerja Pegawai. Maneggio: Jurnal Ilmiah Magister Manajemen, 2(1), $16-30$.

Sutrisno, E. (2014). Manajemen Sumber Daya Manusia. Jakarta: Kencana Prenada Media Group.

Tanjung, H. (2015). Pengaruh Disiplin Kerja Dan Motivasi Kerja Terhadap Prestasi Kerja Pegawai Pada Dinas Sosial Dan Tenaga Kerja Kota Medan. Jurnal Ilmiah Manajemen Dan Bisnis, 15(1), 27-34.

Wahyudi, W. R., \& Tupti, Z. (2019). Pengaruh Budaya Organisasi, Motivasi dan Kepuasan Kerja Terhadap Kinerja. Maneggio: Jurnal Ilmiah Magister Manajemen, 2(1), 31-44. https://doi.org/10.30596/maneggio.v2i1.3363

Yusnandar, W., Nefri, R., \& Siregar, S. (2020). Pengaruh Disiplin Kerja Dan Pelatihan Terhadap Kinerja Karyawan Dengan Budaya Organisasi Sebagai Variabel Moderasi Pada Rumah Sakit Milik Pemerintah di Kota Medan. Jurnal Humaniora : Jurnal Ilmu Sosial, Ekonomi Dan Hukum, 4(1), 61-72. https://doi.org/10.30601/humaniora.v4i1.433 